\title{
Sustainability of the usable solid waste market in Bogota (Colombia)
}

\author{
Sustentabilidade do mercado de Resíduos Sólidos Utilizáveis \\ em Bogotá (Colômbia)
}

María del Pilar Sánchez Muñoz [a] [D], Johan Manuel Redondo [b] [D], José Gabriel Cruz Cerón [c] [D, Danny Ibarra-Vega [d] [D],

Abel Del Rio Cortina [e] [D], Jorge Catumba-Ruíz [d] [D]

[a] Universidad del Rosario, Bogotá, Colombia

[b] Universidad Católica de Colombia, Bogotá, Colombia

[c] Universidad de Caldas, Manizales, Colombia

[d] International Research Center for Applied Complexity Sciences (IRCACS), Bogotá, Colombia

[e] Universidad EAN, Bogotá, Colombia

How to cite: Muñoz, M. P. S., Redondo, J. M., Cerón, Ibarra-Vega, D., Cortina, A. R., \& Catumba-Ruíz, J. (2021). Sustainability of the usable solid waste market in Bogota (Colombia). urbe. Revista Brasileira de Gestão Urbana, v. 13, e20200343. https://doi.org/10.1590/2175-3369.013.e20200343

\begin{abstract}
This document shows a model that seeks the sustainability of the Usable Solid Waste (USW) market in Bogotá, based on System Dynamics (SD), in order to understand the complex behavior of the phenomena that should be presented in this city market in the context of sustainability. Dynamic hypothesis suggests that two negative feedback structures exits, one that represents demand and another that represents supply and that interact under the assumption of free market with government intervention. Different strategies were modeled on both the demand side and the supply side to manage the system. As conclusion, the linear way in which the USW market currently develops is not adequate. It is necessary to institutionalize the market using the price so that it contributes to its sustainability and that both demand and supply are encouraged at the same time. Besides, district policy oriented to supply must be in accordance with the national policy that encourages demand to use more USW. Likewise, the internalization by all the actors of the market and applicability of the norm is required. The creation of public-private partnerships is required for the development of innovative projects in this area.
\end{abstract}

Keywords: Sustainability. Usable solid waste market. Systems Dynamics. Solid waste policy.

\section{Resumo}

o presente documento mostra um modelo que busca a sustentabilidade do mercado de Resíduos Sólidos Utilizáveis (USW) em Bogotá, com base na Dinâmica de Sistemas (SD), para entender o comportamento complexo dos fenômenos que devem apresentar-se neste mercado de cidade no contexto da sustentabilidade. A hipótese dinâmica sugere que há duas estruturas de comentário negativo, uma que representa a demanda e o outra que

\footnotetext{
MDPSM is research professor, doctor in Sustainable Development, e-mail: mariad.sanchez@urosario.edu.co

JMR is research professor, doctor in Engineering, e-mail: jmredondo@ucatolica.edu.co

JGCC is research professor, doctor in Economic Sciences, e-mail: gabocruz@ucaldas.edu.co

DIV is research professor, doctor in Engineering, e-mail: dwibarrave@unal.edu.co

ADRC is research professor, doctor in Project Management, e-mail: adelrioc2311@universidadean.edu.co

JCR is professional in mathematics, master of science in Applied Mathematics e-mail: jorgerev90@gmail.com
} 
representa a oferta, e que interage baixo à suposição de mercado livre com a intervenção do governo. Diferentes estratégias foram moldadas em ambos os lados, tanto demanda quanto oferta, para dirigir o sistema. Como conclusão, o caminho linear no qual o mercado USW atualmente se desenvolve, não é adequado. É necessário institucionalizar o mercado usando o preço de maneira que contribua para a sua sustentabilidade e que tanto a demanda como a oferta sejam estimuladas a mesmo tempo. Além disso, a política de distrito orientada para o fornecimento, deve estar conformada à política nacional que estimula a exigência de usar mais USW. Do mesmo modo, é necessário que todos os atores do mercado internalizem e apliquem as normas. Também é necessária a criação de alianças entre os setores público e privado para o desenvolvimento de projetos inovadores nesta área.

Palavras-chave: Sustentabilidade. Mercado de Resíduos Sólidos Utilizáveis. Dinâmica de Sistemas. Política de Resíduos Sólidos.

\section{Introduction 1}

The management of Usable Solid Waste (USW) is complex, which is why in order to solve the different problems it presents, the intervention of all the actors in the value chain is required. Through System Dynamics (SD), the interrelationships of these actors in the structure can be analyzed in a non-linear way.

The evidence collected shows that the policy guidelines on the management of usable solid waste are not put into practice and the rules of the game will not generate incentives in favor of sustainability. Therefore, it is necessary to propose sustainable intervention strategies in the integral management of solid waste, taking into account the local and national context, identifying incentives for the market players of the usable waste to reduce the amount of waste that is disposed of in the landfill and thus contribute to the sustainable and effective management of the system.

The paper focuses on the complex problem of USW management (generated by households), emphasizing those parts that are usable. The solid waste generated by households should, in a small part, be disposed in the landfill, and the other, be reused as raw material for industry. For this, it is required: on the one hand, that the activity of separation in source be done in a responsible and conscious way by (1) households, (2) the recyclers and (3) companies that provide the collection and transport service, these actors play a fundamental role in the integral service process. On the other hand, an industry potentially demanding of this waste is required in order to it can be incorporated into the production process in an innovative way.

Sustainability in the usable solid waste market refers to economic, social and environmental elements that become an opportunity for citizens to live well and promote development; It can also become a determining factor to improve the environmental conditions of cities, with positive repercussions at social and economic levels for all the agents involved in this activity by generating employment and reducing poverty.

In this sense, the global guidelines have gained strength to include the environment in the strategic planning of local public policies. Thus, objective twelve of the seventeen approved at the Summit for Sustainable Development (2015) seeks to guarantee sustainable consumption and production modalities, and within this, one of the indicators is to substantially reduce the generation of waste by 2030 through prevention, reduction, recycling and reuse policies. The above implies carrying out an analysis regarding what and how progress is being made in the design and implementation of public policy for the management of household solid waste in Bogotá, and especially for those that are usable, since increasing its reuse brings the positive consequence of the reduction of material disposed of in landfill.

Some studies have used the SD approach to present alternatives for managing solid waste in households, which were taken into account for the construction of the System Dynamics model of Bogotá and contributed to the selection of intervention strategies. In this context Sudhir, Srinivasan \&

1 This research did not receive any specific grant from funding agencies in the public, commercial, or not-for-profit sectors. Declarations of interest: none. 
Muraleedharan (1997), developed a SD model that captures the dynamic nature of the interactions between public health, the environment, present and future costs for society and the subsistence mechanisms of the informal recycling sector "actors", in a typical metropolitan city in India. The model provides a platform for debate on the potential and systemic consequences of various structural and policy alternatives for sustainable planning of urban solid waste management.

Vásquez (2005) presented a model that allows simulating the impact of a management plan for the administration of residential solid waste in the metropolitan region of Chile. The author concludes that an informative and functional campaign has a significant impact on the amount of waste in landfills and on the costs associated with the production, collection and disposal of household solid waste in the metropolitan region of Chile.

Additionally et al (2007) evaluated a SD model for the management of solid urban waste, in order to determine the potential of electric power generation to meet the energy consumption needs of the city of Dhaka. (Bangladesh). The authors conclude that a solid urban waste management system must contain economic, social, technological, environmental and political aspects. Finally, they stated that increasing collection capacity alone does not improve the quality of the environment and that an increase in the budget allocation for the collection and treatment of waste is necessary to improve the environmental quality of the city of Dhaka.

In addition, Ibarra et al (2010) built a model using the methodology of SD, for the regionalization and sustainable management of municipal solid waste in Colombia and concluded that "for an integral solid waste management plan, to be efficiently implemented, an appropriate investment rate is needed, and that this corresponds to the population of the institution" (p. 36).

Likewise et al (2010) developed a dynamic model incorporating, to a certain extent, the complexity of the waste generation and management process, through a combination of simpler subprocesses that come together to form a whole. The authors explore the impact of decision options on the generation of waste in the city of Newark, USA, the life of the landfill and the cost or economic benefit updated by different waste processing options, providing valuable information on the management of urban waste.

Ávila et al (2011) presented, through SD, the analysis and evaluation of the impact generated in an Integrated Solid Waste Management System due to the increase in waste associated with population growth in the city of Santiago de Cali. They reached the conclusion that "conducting awareness campaigns and establishing policies that reduce the generation of waste by the population, as well as the separation and use of them at the source, have a great impact on the system of analysis" (p. 9).

Moreover et al (2013) developed a model using SD to simulate the impact of a management plan for the administration of residential solid waste in the urban area of the city of Huancayo (Junín Region, Peru). The model proposed alternatives for recycling and composting in a treatment plant, prior to disposal in the landfill. The main conclusion was that the information and functional awareness that allows the segregation of waste at the source, has a significant impact on the amount of waste in landfills and the costs associated with production, collection and disposal of household solid waste in the urban area of Huancayo.

Finally et al (2016) proposed a SD model whose structure is based on sociological and economic studies on how incentives and social norms interactively affect waste disposal behaviour, based on fieldwork in low-income urban neighbourhoods in Baltimore, MD, USA. The results of the simulation show the effects of individual interventions, and identify the positive interactions between some possible interventions, especially information and incentive-based policies, as well as their limitations.

This document consists of four parts, including the present introduction. The second part methodology is described; the third part we develop a model, with its corresponding validation and intervention strategies. Finally, the conclusions of the research are presented. 


\section{Methodology}

In this research, systemic modeling was used to explain the parts and the relationships that exist between them, oriented to the management of USW system. Quantitative elements are used with the Forrester diagram ${ }^{2}$; and qualitative with causality diagrams ${ }^{3}$ (Figure 1).

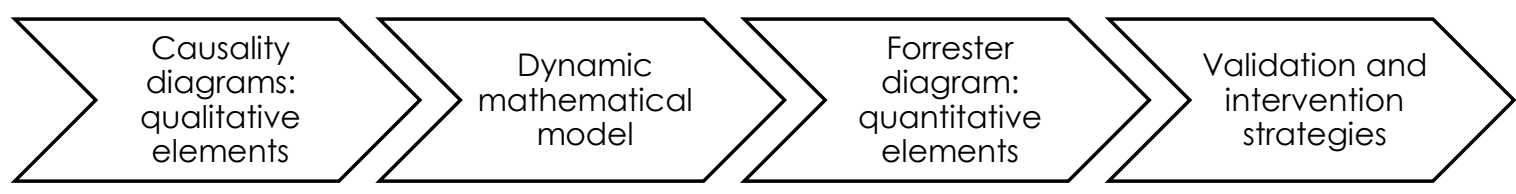

Figure 1 - Methodology. Source: Authors (2018).

System Dynamics was applied as the methodology because the solid waste system of the city is a nonlinear and a temporary problem. The dynamic mathematical model developed is aimed at describing how the market for USW in general should work and not particularly in each sector (glass, paper, plastic, etc.), using price as an institutional framework. This, given that currently the policy in this sector is aimed at increasing supply and not to encourage demand and the few companies that buy the solid waste available have market power.

Information was taken from Bogotá, for the design of the SD model, which explains how the market for USW should behave. Additionally, for the construction of the model, experts were consulted, as a method of collecting relevant and significant data. In addition, this method allowed us to go beyond merely statistical information, because it allowed us to generate and discover elements of analysis based on the experience of the actors consulted. Information was also obtained from secondary sources of Special Administrative Unit for Public Services (UAESP, by the Spanish initials), which allowed the registration of the initial (current) state variables and the change ratios required for a time horizon of 20 years.

It should be noted that the solid waste sector in Bogotá has an unreliable database, given that different methodologies for collecting and systematizing information have been used over the years. In the country there is the Unified Information System (SUI, by the Spanish initials) and in the case of Bogotá, the information provided by the Special Administrative Unit for Public Services (UAESP, by the Spanish initials).

Likewise, information was obtained from the National Administrative Department of Statistics (DANE, by the Spanish acronym) on the population of the city, births and deaths. In addition, the District Planning Secretariat on the net migration rate. From the Statistical System of Foreign Trade (SIEX, by the Spanish acronym) of the Directorate of National Taxes and Customs (DIAN, by the Spanish initials) established the prices of imported virgin raw material that is substitute for solid waste usable in the processes of production of goods. Based on this information, an aggregate mathematical model was constructed with which general conclusions were reached for the institutionalization of USW.

The systemic waste model proposed in this research is the one that generates profitability for recycling organizations, that is, usable waste that can be marketed without costly additional processes that reduce the profitability of them. This USW falls into the competition game between recycling organizations and companies that use them as raw material in their production process.

\footnotetext{
2 This allows writing of the equations that explain the causal diagram in order to validate the model, observe the temporal evolution of the variables. It is also called "flow and level diagram" is the same "causal diagram", or at least it should be, but in the first one the attributes of the causal diagram are distinguished as level variables (state variables), flows (change reasons), auxiliary variables and parameters" (Redondo, 2011, p. 31).

${ }^{3}$ They illustrate the feedback structure of the system, that is, how one variable relates to others and vice versa. "Thus, systemic representations are constructed with arrows and points, called causal diagrams, which capture all the hypotheses proposed by the modeler, learning from the system to intervene on it in the exercise of decision" (Redondo et al 2018a, p. 320). According to Cruz "a well-constructed causality diagram is a good basis for applying modeling or simulation techniques in systems dynamics" (2005, p. 100).
} 
The model consists of three modules built from the demand and supply of USW and their generation. It should be noted that the model is used to examine the general patterns temporarily, that is, to analyze the trends of the state variables within the structure.

This model is designed to explain the behavior of the market of solid waste. It can be used in an aggregate way, as a whole, and not of specific usable waste which behavior is particular; this is the case, for example, of glass, where the percentage of use is $50 \%$ or that of plastic in which $11 \%$ is used, while the organic material goes almost entirely to Doña Juana Landfill.

\section{Demand for usable solid waste}

Currently, companies that use usable waste as raw material, demand this product without taking into account its price compared to raw material, but according to needs already pre-established within their production processes. Little innovative development that is observed to make greater use of usable waste and the costs of its incorporation into the production process are still high.

However, for this first module a negative feedback loop 4 is assumed, which shows the inverse relationship between the price of USW and its demand, in line with economic theory. In turn, a higher demand for the USW generates a lower reserve margin, which expresses the percentage excess or deficit of the demand with respect to the supply, causing the price of the USW to increase.

It is observed that the increase of USW rises the reserve margin, which causes a reduction in its price, and therefore in the profitability of the recycling organizations.

In this module, the state variable is the demand for USW (D_USW), measured in tons per year. The change in the demand for USW with respect to time is given by equation 1.

$$
\frac{d}{d t} D_{U S W}=N I_{D}
$$

Where $N I_{D}$ corresponds to the net increase in demand, and is obtained from the multiplication between the rate of net increase in demand $\left(R N I_{D}\right)$, the demand for USW $\left(D_{U S W}\right)$ and the effect price on the demand $(E P D)$ (equation 2), which corresponds to a dimensionless variable.

$$
N I_{D}=R N I_{D} \cdot D_{U S W} \cdot E P D
$$

The effect of price on demand $(E P D)$ is a dimensionless function and it is obtained with the relationship between the reference price $\left(P_{R E F}\right)$ and the price of USW $\left(P_{U S W}\right)$, raised to the price elasticity of the demand $(\varepsilon)$ (Redondo, Olivar, Ibarra, \& Dyner, 2018b), as shown in equation 3. The price elasticity of demand must be a whole number, positive and not zero, which shows the sensitivity of the industry (who demand this waste to be used as raw material) to percentage changes in the price. It is expected that when the price of USW is low, the consumption of this waste will increase and when the price increases, this consumption will decrease, applying the law of demand.

$$
E P D=\left(\frac{P_{U S W}}{P_{R E F}}\right)^{-\varepsilon}
$$

In addition, following Redondo et al (2018b) equation 4 present the price of USW was constructed $\left(P_{U S W}\right)$, modeled as a sigmoidal function of the reserve margin. The price is a decreasing function of the reserve margin $\left(R M_{U S W}\right)$. That is, for high values of the reserve margin, the price tends to the minimum value $\left(P_{\text {min }}\right)$, given in pesos per ton of USW, which protects recycling organizations. If the reserve margin presents low values, the price tends to the maximum value $\left(P_{\max }\right)$ which protects the industry from paying

\footnotetext{
${ }^{4}$ Forrester affirms that there is feedback when the environment or situation in which the system is located gives rise to a decision whose result is an action that, in turn, influences that means and therefore, future decisions (Forrester, 1961). A feedback loop is a closed chain of causal relationships.
} 
extra costs for the purchase of this waste, which is then used as raw material and corresponds to the sum of the minimum price and the variation between the maximum price and the minimum price.

$$
P_{U S W}=\frac{P_{\max }-P_{\min }}{1+e^{R M} U S W}+P_{\min }
$$

By modeling the price in this way, the dynamics of the USW market can be represented. Thus when the reserve margin tends to the left of zero (excess percentage of demand), the price tends to increase; When the reserve margin moves to the right (percentage deficit of demand), the price falls as necessary to reach equilibrium in the market, that is to say, so that the USW that can be used is commercialized efficiently.

The reserve margin for solid waste that can be used $\left(R M_{U S W}\right)$ is a relationship between usable solid waste $(U S W)$ and the demand for such waste $\left(D_{U S W}\right)$ and it is dimensionless and positive. Its mathematical expression is in equation 5.

$$
R M_{U S W}=\frac{U S W-D_{U S W}}{U S W}
$$

Which expresses the excess/deficit percentage of the demand for USW with respect to your supply.

\section{Supply of usable solid waste}

The second module, the supply one, corresponds to a negative feedback loop, as well as the demand one. Here we see how an increase in the price of USW increases profitability for recycling organizations assuming (ceteris paribus) that the costs remain unchanged, which in turn encourages the use by them; in this way, the amount of USW offered in the market increases and therefore increases the reserve margin, causing the price in the market to decrease.

These organizations play an important role insofar as their work depends on the usable material that can be used by the industry as raw material. In Bogotá, 118 recycling organizations are legally constituted, made up of 17,296 member recyclers (Semana Sostenible, 2020); the rest of the agents work informally throughout the city.

Here, the usable solid waste is used as a state variable (USW), measured in tons per year. The change of USW with respect to time is given by equation 6 .

$$
\frac{d}{d t} U S W=U_{R O}
$$

Where $U_{R O}$ is the use of recycling organizations, which in turn is obtained by multiplying the usable rate of recycling organizations $\left(U R_{R O}\right)$ with the amount of household solid waste measured in tons per year $(H S W)$, and with the percentage profitability for recycling organizations $\left(P R O F_{R O}\right)$ (equation 7).

$$
U_{R O}=U R_{R O} \cdot H S W \cdot P R O F_{R O}
$$

The percentage profitability for recycling organizations $\left(P R O F_{R O}\right)$ is obtained in equation 8 , as a proportion with respect to the price of USW $\left(P_{U S W}\right)$, with the difference between the latter and the total unit cost (TUC), in other words, this profitability expresses the percentage ratio of cost to price.

$$
P R O F_{R O}=\frac{P_{U S W}-T U C}{P_{U S W}}
$$

It is true that, within the value chain, recycling becomes subsistence activity for many and a business for just a few. The average daily income of a recycler, who works between 12 and 13 hours, is between USD 2.7 and USD 3.2, which represents a monthly average of USD 81.3. The most expert recyclers receive up to USD 5.4 per day, working up to 17 hours a day. 
On the other hand, the total unit cost (TUC) it is obtained by multiplying the unit cost of the usable solid residues of reference $\left(T U C_{R E F}\right)$ by the negative exponent of the learning coefficient $(\sigma)$ and the relationship between usable solid waste $(U S W)$ and the usable solid waste of reference $\left(U S W_{R E F}\right)$ (equation 9).

$$
T U C=T U C_{R E F} e^{\left(-\sigma \frac{U S W}{U S W_{R E F}}\right)}
$$

There is inverse relationship between the quantities of USW and the unit costs. Assuming increasing returns to scale of the installed capacity for use, causing the total unit costs to decrease as the quantities offered increase, thus presuming economies of scale. In addition to learning curves as time goes by, which translates into unit costs that move to the left (decrease thereof).

\section{Generation of usable solid waste}

The consumption of solid waste by households in Bogotá corresponds to approximately 6,300 tons per day, of which $14 \%$ are recycled. Table 1 shows the behavior of the generation, disposal and use of solid waste between 2014 and 2016. It can be seen that in $201412.8 \%$ of the waste generated in the city was used, in 2015 it increased to $14.8 \%$. However, for 2016 the use was $13.8 \%$.

Table 1 - Generation, Disposal and Use of solid waste

\begin{tabular}{llll}
\hline WASTE & $\mathbf{2 0 1 4}$ & $\mathbf{2 0 1 5}$ & $\mathbf{2 0 1 6}$ \\
\hline Solid waste generated $(t n)^{*}$ & 2.695 .307 & 2.662 .844 & 2.594 .978 \\
Solid waste disposed of in landfill $(t n)$ & 2.351 .131 & 2.269 .533 & 2.253 .072 \\
Solid waste used $(t n)$ & 344.176 & 393.311 & 341.906 \\
\hline
\end{tabular}

Note: * It corresponds to the sum of the solid waste disposed of and the waste used. Source: Secretary of Habitat, Special Administrative Unit of Public Services (2016).

Table 2 shows that the Doña Juana Landfill receives a higher proportion of organic material (42.24\%), which, although it could be used, is disposed of in the landfill, generating leachate and greenhouse gases. They are followed in proportion by plastic with $23.39 \%$, and paper with $9.41 \%$. The rest of materials correspond to $24.96 \%$ of the total weighed during 2015 (Secretary of Habitat, Special Administrative Unit of Public Services, 2016).

Table 2 - Characterization of waste at the final disposal site

\begin{tabular}{ll}
\hline Type of material & $\begin{array}{l}\text { Percentage by weight per } \\
\text { material }\end{array}$ \\
\hline $\begin{array}{l}\text { Organic } \\
\text { material }\end{array}$ & $42,24 \%$ \\
PET & $23,39 \%$ \\
Paper & $9,41 \%$ \\
Textile & $8,13 \%$ \\
Paperboard & $6,26 \%$ \\
Wood & $2,58 \%$ \\
Glass & $2,32 \%$ \\
Others & $1,58 \%$ \\
Aluminum & $1,39 \%$ \\
Rubber & $0,89 \%$ \\
Leather & $0,70 \%$ \\
Brick & $0,41 \%$ \\
Ceramics & $0,34 \%$ \\
Ash & $0,17 \%$ \\
Mineral & $0,11 \%$ \\
Bone & $0,08 \%$ \\
\hline
\end{tabular}


The collection of solid household waste $\left(C_{H S W}\right)$, whose disposal is made in the Doña Juana Landfill, is given in tons per year and corresponds to the percentage of that household waste that is not used $\left(1-U R_{R O}\right)$, multiplied by the amount of solid household waste measured in tons per year $(H S W)$ (equation 12).

$$
C_{H S W}=\left(1-U R_{R O}\right) \cdot H S W
$$

The change in population with respect to time given by the equation 13 :

$$
\frac{d}{d t} P=N I_{P}
$$

Where $N I_{P}$ corresponds to the net increase in the population obtained by multiplying the rate of net increase in the population $\left(R N I_{P}\right)$ by the total population $(P)$ (equation 14). $R N I_{P}$ includes the birth rate, minus the mortality rate, plus the net migration rate of the city.

$$
N I_{P}=R N I_{P} \cdot P
$$

\section{Model assessment}

According to Barlas (1996), "The general logical order of the validation is to first prove the validity of the structure, and then begin to test the accuracy of the behavior, only after the structure of the model is perceived as adequate" (p. 188). Here, the mathematical model is validated in its structure by its dimensional consistency, consistency in its formulation and in the units of measurement used. Its logical structure and the causal relationship were verified with the literature review and the information collected through the experts. The complete causal diagram can be seen in Figure 2. Thus, dynamic hypothesis suggests that two negative feedback structures exists, one that represents demand and another that represents supply; and that interact under the assumption of free market with government intervention.

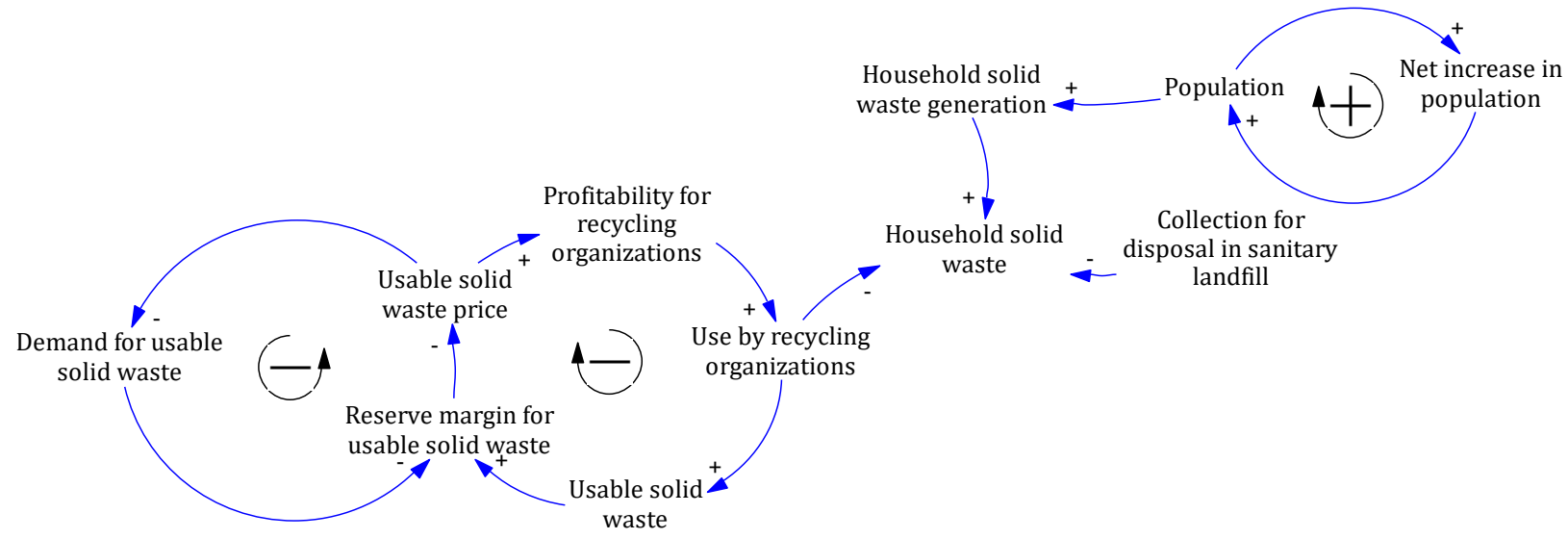

Figure 2 - Causal diagram of the USW market. Source: Authors (2018).

In other words, companies demand potentially usable waste as raw material for their production processes. These wastes are offered by recycling organizations. The interaction between buyers and sellers depends on the price of the residue. A high price benefits the bidders, but the demanders prefer to pay a lower price, which is why government intervention is necessary on the price and on the incentives for demand to push supply. Likewise, supply depends on the generation of usable solid waste by households (population). As source separation is better, the waste that can potentially be reused in the industry is greater and the amount that is disposed of in the landfill is less. 
The mathematical modeling of the elementary structure of the system can be seen in Figure 3, formed by four state variables. This modeling represents how the usable solid waste market should function in Bogotá, based on neoclassical theory. It should be clarified that according to this theory, the price is determined by the interaction between demand and supply. When the supply is greater than demand, the price falls. When the first is less than the second, price goes up. This has been captured in the model through the reserve margin.

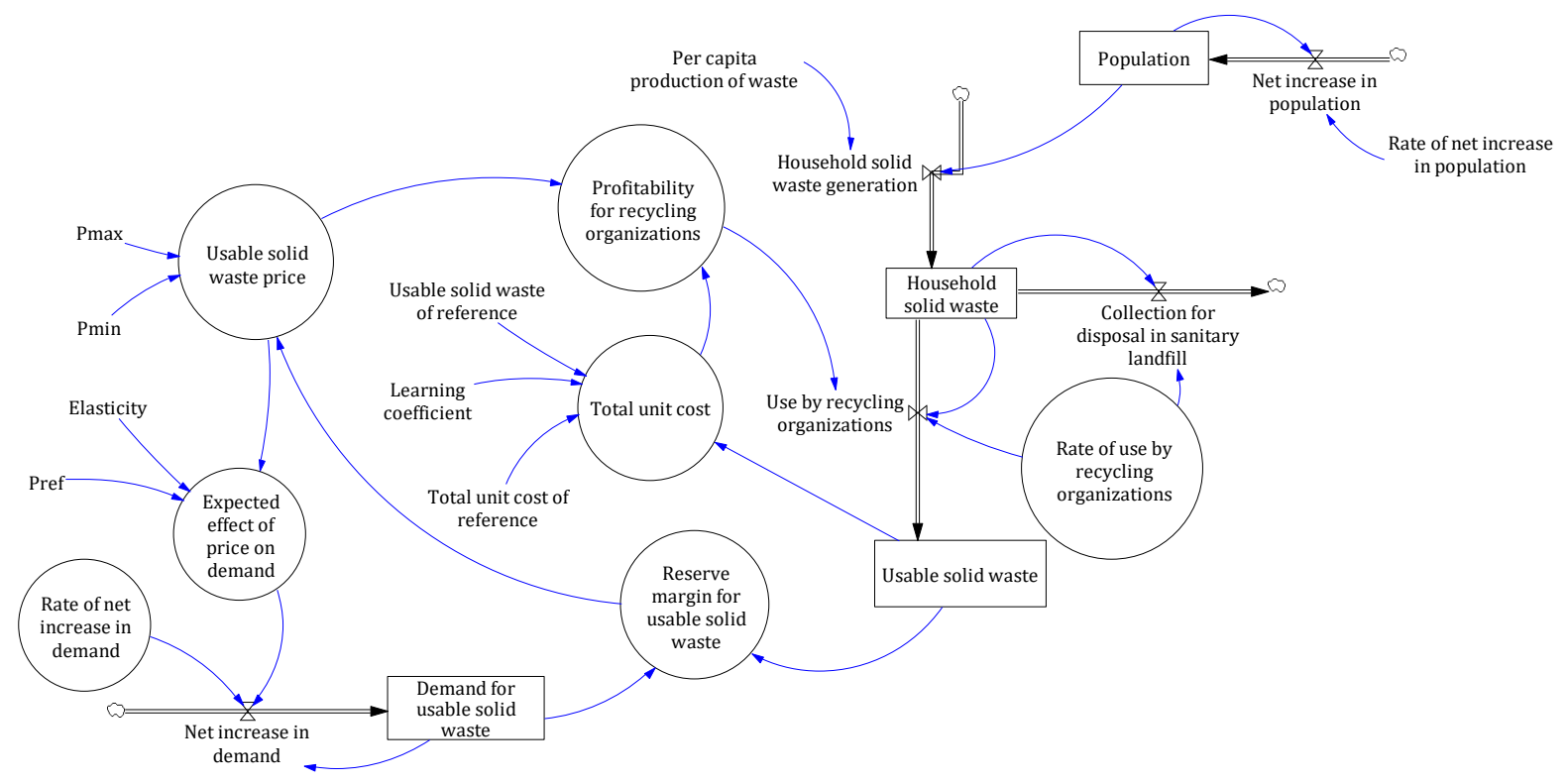

Figure 3 - Forrester diagram of the USW market. Source: Authors (2018).

In this sense, the model allows us to see the trend of the state variables over time. These variables are population, household solid waste, usable solid waste and the demand for the latter by the industry. The changes in the state variables depend on the rates of change and the auxiliary variables described in equations (1) to (14). Figure 4 schematically shows the attributes of the mathematical model.
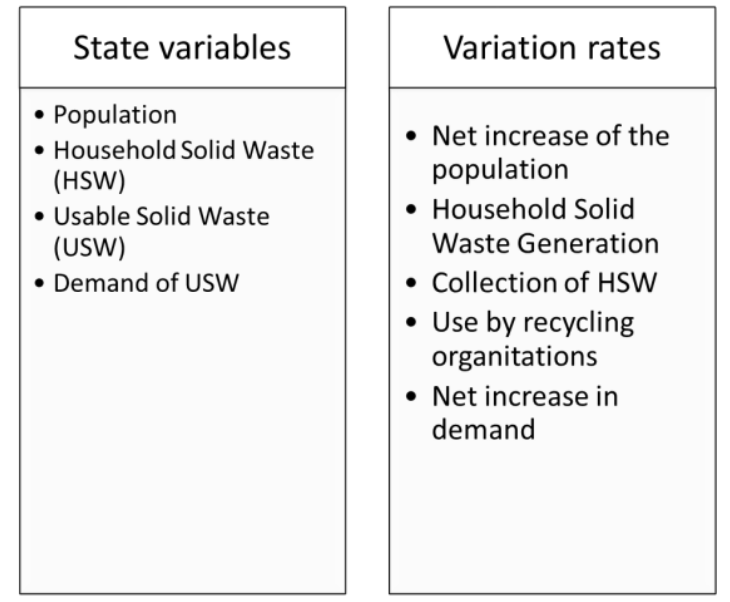

\begin{tabular}{|l|}
\hline Auxiliary variables \\
\hline - Reserve margin \\
for usable solid \\
waste \\
- Total unit cost \\
- Profitability for \\
recycling \\
organizations \\
- Price of USW \\
- Expected effect of \\
price on demand \\
\end{tabular}

Figure 4 - Model attributes. Source: Authors (2018).

This is the result of a mathematical model, which is a USW model for Bogotá to represent a 3dimensional system of non-linear ordinary differential equations, assuming the population is an exogenous variable, as shown in equation 15. 


$$
\begin{gathered}
\frac{d D_{U S W}}{d t}=R N I_{D} \cdot D_{U S W} \cdot\left(\frac{P_{\max }+P_{\min } e^{1-\frac{D_{U S W}}{U S W}}}{P_{\text {ref }}\left(1+e^{1-\frac{D_{U S W}}{U S W}}\right)}\right)^{-\varepsilon} \\
\frac{d U S W}{d t}=U R_{R O} \cdot H S W \cdot\left(1-\frac{1+e^{1-\frac{D_{U S W}}{U S W}}}{\left.P_{\max }+P_{\min } e^{1-\frac{D_{U S W}}{U S W}} \cdot T U C_{R E F} e^{\left(-\sigma \frac{U S W}{U S W_{R E F}}\right.}\right)}\right) \\
\frac{d H S W}{d t}=P P W \cdot P-H S W\left(1-U R_{R O} \cdot \frac{1+e^{1-\frac{D_{U S W}}{U S W}}}{\left.P_{\max }+P_{\min } e^{1-\frac{D_{U S W}}{U S W}} \cdot T U C_{R E F} e^{\left(-\sigma \frac{U S W}{U S W}\right)}\right)}\right) \\
\frac{d P}{d t}=R N I_{P} \cdot P
\end{gathered}
$$

The values in Table 3 correspond to the initial conditions of the model and to the data that was taken into account for the parameters. It also takes into account the secondary information obtained, the information collected through interviews with experts and the extreme conditions test. This in coherence with Sterman (2000) who states that limitations in the availability of numerical data mean that it is often impossible to estimate all parameters in a model. The ability to estimate the parameters in a judicious way must be developed using expert opinion obtained through interviews, workshops, archival materials, direct experience and other methods (2000, p. 867).

Table 3 - Initial conditions and parameters

\begin{tabular}{lll}
\hline Parameter & Value & Unit of measurement \\
\hline Initial population (average 2014 to 2016) & 7.878 .783 & Population \\
Initial solid household waste (average 2014 to 2016) & 2.679 .076 & Tons \\
Initial USW (average 2014 to 2016) & 359.797 & Tons \\
Initial demand for USW (average 2014 to 2016) & 359.797 & Tons \\
Rate of net increase of the population & 0,01254583 & Tons/year \\
Per capita production of waste & 0,302325 & l/year \\
Rate of net increase in demand & 0,01 & l/year \\
Rate of use of recycling organizations & 0,3 & USD/Tons \\
Reference price for USW & 1.941 & USD /Tons \\
Maximum price of USW & 2.181 & USD /Tons \\
Minimum price of USW & 1.701 & USD /Tons \\
Total unit cost of reference & 1.585 & Adimensional \\
Elasticity & 1 & Adimensional \\
Learning coeficiente & 0,5 &
\end{tabular}

Source: Authors (2018).

In addition, tests of extreme conditions of the parameters were carried out following Forrester and Senge (1980), that is, the rates of change and their levels established in the model were examined; the extreme values of 0 and 1 and an intermediate value of 0.5 were taken. For example, if the rate of use of the recycling organizations is zero, all the USW will be disposed in the landfill. It is also observed that the variation of USW is direct and proportional to the change in this rate, that is to say, the effort in use is evenly distributed. It should be noted that changes in the rate of use have no effect on the demand for this waste.

With respect to the changes in the learning coefficient, if this is zero, the total unit costs are very high and if it is one these costs are reduced. If this coefficient varies between 0 and 0.5 , significant changes are reflected in the reserve margin, the percentage profitability and the USW. This shows that the initial efforts to increase the knowledge and experience in the harvesting processes generate important changes. On the other hand, if the coefficient is between 0.5 and 1 , the changes in these three variables are not significant. 
This suggests that public policy should aim to increase the learning coefficient to $0.5 \%$ by implementing different strategies and relying on institutions such as the National Apprenticeship Service (SENA).

Likewise, the values extreme test revealed that demand changes significantly when the rate of net increase in demand varies. This makes it presume that changing market demand changes market conditions. If the net rate of demand is zero, the demand is also zero; incremental changes in this rate of 0.05 generate uniformly distributed increases in demand.

Regarding the elasticity, it took values between one and five to analyze the behavior of the demand for usable waste to variations in this parameter, shows the little sensitivity that exists in the demand to variations in elasticity.

\section{Intervention Strategies in the USW Market}

Taking into account the revised background and the expert judgment, the proposed Forrester diagram incorporates the management strategies on the elementary structure of the USW market. Among the strategies proposed are those that directly intervene the use by recycling organizations $\left(U R_{R O}\right)$ and those that affect the demand for USW $\left(R N I_{D}\right)$ (Figure 5). The assumption here is that these strategies are rates of change that can take any value between zero and one.

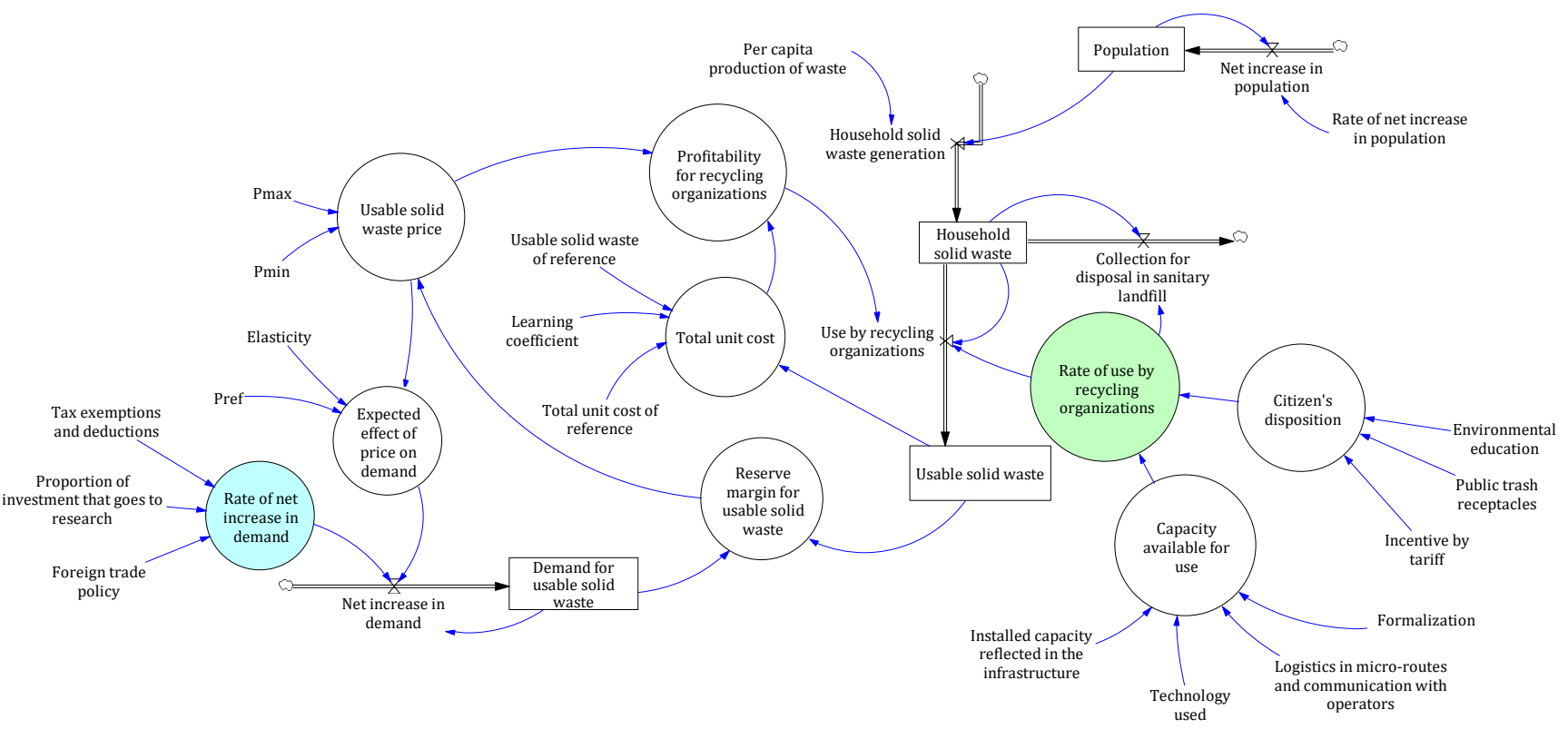

Figure 5 - Forrester Diagram with strategies. Source: Authors (2018).

Table 4 presents, for each of the strategies, the referents that were taken into account to decide the proportions used in equation 16 to 19. 
Table 4 - Strategies' referents

\begin{tabular}{|c|c|c|}
\hline Strategies & & References \\
\hline Citizen's disposition & $\begin{array}{l}\text { Environmental education } \\
(E E) \\
\text { Public trash receptacles } \\
(T R) \\
\text { Incentive that the CRA } \\
\text { proposes in its tariff }(T I)\end{array}$ & $\begin{array}{l}\text { Naime \& dos Santos (2011) } \\
\text { Vásquez (2005) } \\
\text { Peña \& Rojas (2013) } \\
\text { Expert judgment } \\
\text { Ávila et al(2011) } \\
\text { Expert judgment } \\
\text { Breukers (2017) } \\
\text { Sudhir et al (1997) } \\
\text { Guo et al (2016) } \\
\text { CRA. Resolución } 720 \text { de } 2015 \\
\text { Expert judgment }\end{array}$ \\
\hline $\begin{array}{l}\text { Installed capacity } \\
\text { available for use }\end{array}$ & $\begin{array}{l}\text { Logistics in micro-routes } \\
\text { and communication with } \\
\text { operators }(L O) \\
\text { Installed capacity } \\
\text { reflected in the } \\
\text { infrastructure }(I) \\
\text { Technology used }(T)\end{array}$ & $\begin{array}{l}\text { Ministerio de Vivienda, Ciudad y Territorio. Resolución } 276 \\
\text { de } 2016 \\
\text { Expert judgment } \\
\text { Franchetti \& Spivak (201 1a, b) } \\
\text { Ministerio de Vivienda, Ciudad y Territorio. Resolución } 276 \\
\text { de } 2016 \\
\text { Expert judgment } \\
\text { Meira de Sousa Dutra et al (2018) } \\
\text { CRA. Resolución } 788 \text { de } 2017 \\
\text { Expert judgment } \\
\text { Fidelis et al (2015) } \\
\text { Expert judgment }\end{array}$ \\
\hline Demand & $\begin{array}{l}\text { Tax exemptions and } \\
\text { deductions }(T E) \\
\text { Proportion of investment } \\
\text { that goes to research }\left(I_{I \& D}\right) \\
\text { Foreign trade policy }(F T P)\end{array}$ & $\begin{array}{l}\text { Breukers (2017). } \\
\text { Expert judgment } \\
\text { Organization of American States (2016). } \\
\text { CONPES 3874. (21 de November de 2016). } \\
\text { Elizande (2009). } \\
\text { Expert judgment } \\
\text { Expert judgment }\end{array}$ \\
\hline
\end{tabular}

Source: Authors (2018).

The first group includes those that alter the citizen's disposition $(C D)$ towards the generation and management of solid waste at home. Such as environmental education $(E E)$ that the district plans to implement, public trash receptacles $(T R)$ that the operators must install and the incentive that the CRA ${ }^{5}$ proposes in its tariff (TI) for those who do separation in source or sanctions for those who do not. The modelling was based on the assumption that the tariff incentive has an effect of $50 \%$ on the disposition of citizens, while the other two strategies weigh $25 \%$ each.

$$
C D=0,25 E E+0,5 T I+0,25 T R
$$

Also, in this group are those related to the collection capacity of recycling organizations, measured by the installed capacity available for use $(C A U)$ as for example, its formalization $\left(F_{R O}\right)$ (Resolución 276 de 2016), logistics in micro-routes and communication with operators $(L O)$ and its installed capacity reflected in the infrastructure $(I)$ and in the technology used $(T)$. The assumption is that each of the four strategies has the same share (equation 17). 


$$
C A U=0,25 F_{R O}+0,25 L O+0,25 T+0,25 I
$$

In this way, the rate of use of recycling organizations $\left(T A_{O R}\right)$ is expressed by equation 18.

$$
U R_{R O}=0,14+0,36 C A U+0,5 C D
$$

About the strategies that affect the demand for USW, tax exemptions and deductions (TE) could be made to companies that use this waste as raw material. Another strategies would be the proportion of investment that goes to research $\left(I_{I \& D}\right)$ for the efficient use of this raw material in the production process; and finally foreign trade policy (FTP) in order to limits the importation of virgin raw material. Concerning research, projects must be developed in partnerships between academia, the public sector and private enterprise.

Such strategies are of National order and currently the policy for solid waste management has a lack in that matter. Based on the judgment of experts and the review of the literature, the weight given to the effect of the foreign trade policy on the rate of net increase in demand was, $15 \%$, on research $25 \%$, and it is considered that the effect of the tax reductions corresponds to $59 \%$. This is due to the interests of the industry to reduce its costs in the production process both in the short and long term. Therefore, the rate of net increase in demand $\left(R N I_{D}\right)$ is expressed as equation 19.

$$
R N I_{D}=0,01+0,25 I_{I \& D}+0,15 F T P+0,59 T E
$$

Strategies alone will not be effective if, in the future, (1) it is cheaper to bury waste instead of recycling it. (2) If it is more expensive to comply with the institutional framework than not doing it (Martínez Alier \& Roca, 2013). (3) If research of technological and social innovation is not developed. (4) If the logistics to transport the USW to the industry incurs excessive transaction costs. (5) If the information system of the sector is still poor.

Additionally, it is required by the State, a strong commitment to training entrepreneurs, for example through SENA, and an increase in the budget that the Ministry of Housing, City and Territory allocate to science, technology and innovation projects for water and solid waste, which is only $0.13 \%$ at present. Likewise, it is necessary to build projects for the transformation of USW financed with international cooperation resources or subsidies.

Following the strategies outlined in the current national and district environmental policy, it is observed that there is a bias on supply through strategies that seek to change the disposition of citizens to separate in source and increase the amount of USW, as well as a willingness to improve the installed capacity of recycling organizations in logistics, administrative and corporate aspects.

In a first scenario, where the application of the strategies make all the rates of change equal to 0.5 , it is observed that the system is more sensitive to changes in the rate of net increase in demand $\left(T_{I} N_{D}\right)$ than to the rate of use of recycling organizations $\left(T A_{O R}\right)$; Figure 5 shows how the demand for USW increases compared to the supply.

Additionally, in a second scenario, if a value of one is assumed for the parameters that affect the rate of use of recycling organizations, and the demand remains constant, the current policy for solid waste management is fully effective. This result in the supply being relatively large with respect to demand (Figure 6) and the reserve margin becomes asymptotic towards one. Under these conditions, the price of USW that can be used becomes so small that profitability for recycling organizations becomes negative.

The above statements suggest that the challenges of solid waste management face the technical, administrative, regulatory and social issues. A structural change is required, so that the solid waste management policy takes into account intervention strategies that increase the demand for USW for the market to work efficiently. These strategies include tax reductions for companies that make use of this material within their production process and support for research that allows the efficient use of this raw material and allows the generation of quality final goods with aggregate value, as proposes the sustainable closed cycle production approach. 
It is also necessary to establish a foreign trade policy that limits the entry of imported virgin raw material at lower prices than USW, because when imported raw material enters the domestic market at a lower price, the waste that it substitutes goes in greater proportion to landfills.

It is necessary that environmental education transcend to the "environmental culture", so that the actors' actions result in solid waste management, consistent with the circular economy. Therefore, short, forceful and precise educational campaigns are required. In addition, comprehensive solid waste management plans must be binding between the State, private companies and citizens. It is a State duty to carry out control and guarantee compliance with the norm.

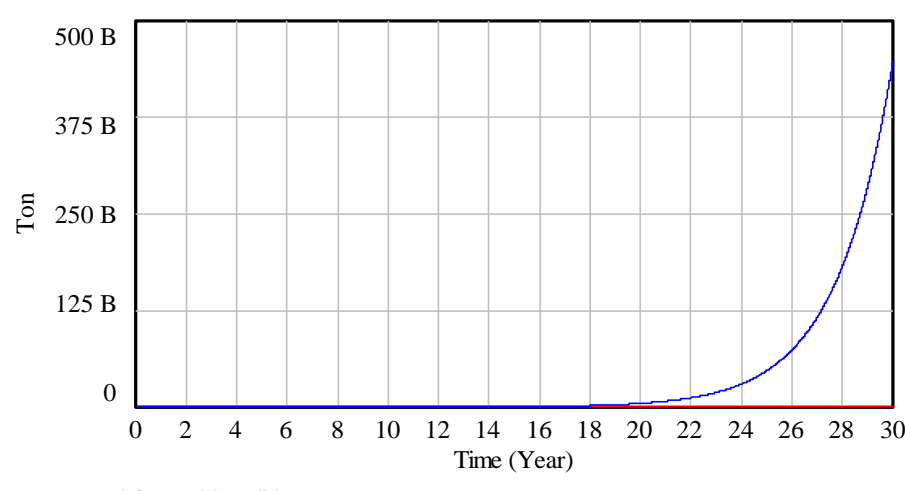

Demand for usable solid waste Usable solid waste

(a)

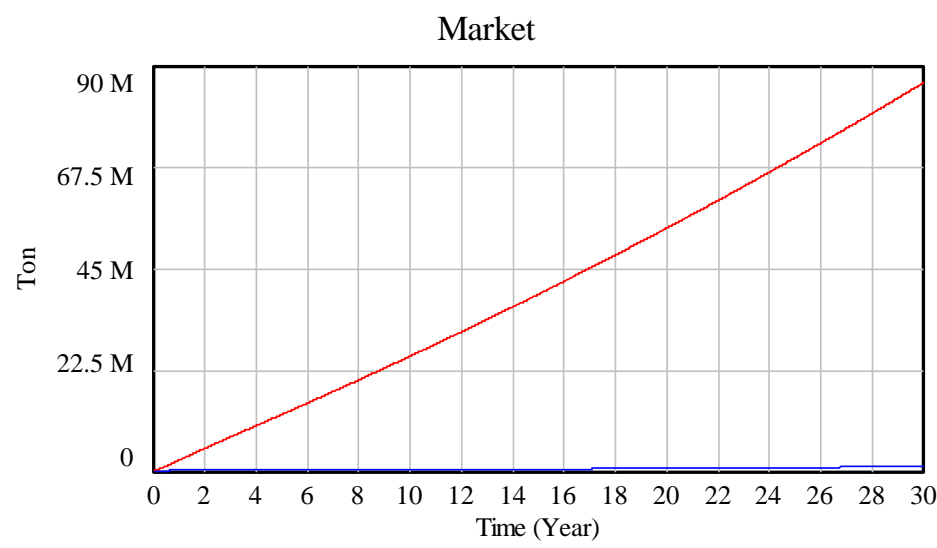

Demand for usable solid waste

Usable solid waste

(b)

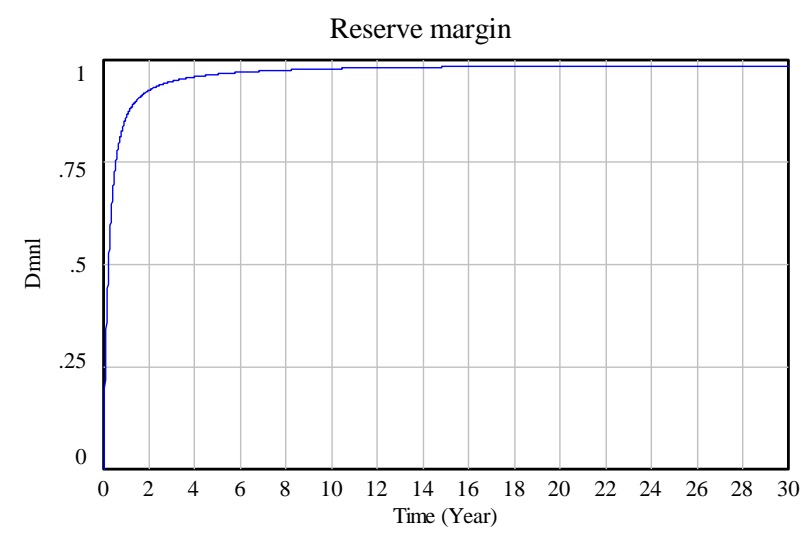

(c)

Figure 6 - Effects with scenarios. (a) Effects with scenario 1; (b) and (c) Effects with scenario 2. Source: Authors (2018). 
It should be clear that the source of the problem is not the separation in source by itself; it is the dynamics of consumption of the capitalist process and the lack of a clear policy for demand, which is why the paradigm change of the real development model is imperative. Cortina (2002, quoted by Elizande, 2009), raises the urgency of changing current forms of consumption, because they lead to unsustainable ways of life and states that to live sustainable forms of life it is essential to introduce the principle of negative universalization: "never consume products whose consumption cannot be universalized without causing damage to people or the environment" (Elizande, 200, p. 66).

\section{Conclusions}

The dynamic hypothesis that there are two negative feedback structures is verified. One that represents demand and another that represents supply. It is desirable that these two structures interact under the assumption of free market with government intervention so that the model can integrate the social, environmental and economic dimensions, in such way that a balance is presented between the actors of the system and sustainability.

The model represents, from the economic point of view, the dynamics of a competitive market with State intervention. With respect to the social dimension, to the extent that through the dynamics of the competitive market the reserve margin decreases, the price of usable solid waste (USW) increases, then the profitability of recycling organizations increases and therefore recyclers' income and also their quality of life.

From an environmental point of view, a greater use of household solid waste would reduce the amount disposed at Doña Juana Landfill. For example, if 100 tons are generated and the utilization rate remains at the current percentage, 14 tons would be used and 86 tons would be buried. However, if the system is intervened with the proposed strategies on the demand and supply side, the utilization rate increases, as observed in the scenarios proposed. Thus, a higher utilization rate, for example $50 \%$, would mean that the industry is using 50 tons as raw material in its production process and that 36 more tons are no longer put in the landfill, which results in a tendency to reduce greenhouse gases and the generation of leachate.

The main relationships derived from system dynamics are expressed through level and flow diagrams, also called Forrester diagrams, presented in the development of the research. By constructing the Forrester diagram with mathematical equations, a model of how the usable solid waste market should function is represented, based on neoclassical theory, for the city of Bogotá. This model shows how this market should be and the advantages of the intervention strategies, namely: increase the use of waste, benefit for the industry that uses waste as raw material, contribute to the environment and profitability for recycling organizations, and thus improve their quality of life. The model shows the trend of these attributes over time.

When comparing the model proposed through the Systems Dynamics with the current structure of the usable household waste market in Bogotá, it is observed that based on the scenarios proposed, there is no response capable of integrating human beings with nature. For example, it was observed in scenario 2 , that if the conditions of the usable solid waste market remain unchanged, the profitability of recycling organizations becomes negative, making the activity unsustainable for the recyclers of Bogotá, who will continue receiving poor pay for their work, with a poor quality of life. In addition, instead of taking advantage of waste materials, it will continue to be deposited in the landfill.

In this sense, the proposal presented here offers integral advantages by making it possible to show how the system can be intervened, with special emphasis on those strategies that encourage the demand for USW, to guarantee the basic social rights of justice and decency for all citizens, besides ensuring environment protection.

Therefore, it is key to massify awareness campaigns about the importance of separating materials in the source and the proper use of containers and colored plastic bags so that citizens generate a change of attitude. Likewise, the change in cultural values must be worked harder through environmental education. 
In other words, a public policy is required that involves at least strategies of structural citizen culture to make citizens aware of their responsibility for their generated waste; and adaptation of city furniture so that the recycling activity is more efficient, by having spaces for its disposal.

It was identified, based on the background review, that the policy is built so that the landfill operators and those who carry out the collection logistics management obtain profits (favoring a few private companies and not society as a whole), and it is not focused on solving environmental problems. On the one hand, the source separation policy does not encourage citizens to apply it because they do not obtain direct benefits (incentives) in the short term, which makes the rate incentive strategy, included in the model, key to intervene in the system.

With regard to recyclers, as mentioned before, their work becomes mere subsistence activity and a business for very few. Although the policy proposes the inclusion of this population, the way the market currently works makes them the least benefited within the value chain. However, the formalization strategy is the first step to dignify this activity, and for that reason it is contemplated in the regulations, it is not enough to make the material recovery activity efficient. It is essential to establish the collection micro-routes (logistics strategy) to avoid competition that is generated between the collection operators and the recycling organizations. It is also necessary to seek financing mechanisms so that these organizations can acquire adequate infrastructure and technology to improve the quality of the supply of usable solid waste (USW). These strategies were included in the constructed model.

It is necessary that all goods-producing companies adopt measures that allow them to move towards green production with social responsibility. Specifically, and based on scenario 1, it can be concluded that district policy oriented to supply solid disposable waste must be in accordance with the national policy that encourages demand to use more USW, ensuring that it is less expensive than virgin raw material, which is a substitute factor in the process of production. The creation of public-private partnerships is required for the development of innovative projects in this area (research and development strategy) and encourage industrialists to use USW within their process, through tax exemptions.

In addition, the policy on solid waste cannot be based on the preferences of the government in office; this must be built for the long term and must be done with a systemic approach because the system is complex and the interaction of all the actors depends on their success in the fulfilment of the objectives. The legislative framework must have clearly defined deadlines and objectives. On the other hand, there is a lack of regulation by the State in the market for usable solid waste. It is necessary to direct these efforts not only towards supply, but also towards demand. There are formal rules of the game but there is no "institutionality", the mere existence of the norm is not enough; it also requires internalization by all market players and their use.

In addition, comprehensive solid waste management plans must be binding between the State, the private companies and citizens. The State must carry out the control and guarantee compliance with the norm. In general, it can be said that the strategy to improve the management of solid waste must be comprehensive; therefore, this must include elements of a technical and institutional level, using clear and credible rules that truly persuade the citizen.

Emphasis must be placed on instruments to promote the circular economy, including linking the business sector throughout the cycle of solid waste management, incorporating the environmental costs of the process, for which the measurement of externalities is required, increasing the use of potentially reusable material and, last but not least, change the paradigm of production and post-consumption processes. In other words, it requires political will and greater commitment from private companies to improve the management of solid waste.

The challenges of the solid waste management go through the technical, the administrative, and the regulatory to the social. A structural change is required, so the solid waste policy take into account intervention strategies that increase the demand for USW so that the market works efficiently.

Based on the former ideas, some future lines of work are revealed, such as: (1) The construction of systemic representations of the real situation of the USW sectors that nowadays have a market and have regulations, in order to have a complete characterization. (2) The identification of transition scenarios, in 
relation to strategies for the management of supply and demand for USW. (3) The preparation of documents with public policy guidelines for the management of solid waste.

\section{Bibliographic references}

Ávila, S., Nieto, M., Jiménez, D., \& Osorio, J. (2011). Análisis del impacto generado en un sistema de gestión integral de residuos sólidos por el aumento de los residuos al crecimiento de la población a través de Dinámica de Sistemas. La Dinámica de Sistemas: un paradigma de pensamiento. $9^{\circ}$ Encuentro colombiano de Dinámica de Sistemas. Bogotá: Universidad del Rosario.

Barlas, Y. (1996). Formal aspects of model validity and validation in system dynamics. System Dynamics Review, 12(3), 183210. doi: https://doi.org/10.1002/(SICI)1099-1727(199623)12:3<183::AID-SDR103>3.0.CO;2-4

Breukers, L. (Abril de 2017). The European experience of (Pay As You Throw, PAYT). Conferencie presented at XVII Congreso Internacional en Gestión Integral de Residuos y Perspectivas Ambientales. Prevención, Reutilización y Sostenibilidad.

Cruz, G. (2005). Economía aplicada a la valoración de los impactos ambientales. Manizales: Universidad de Caldas.

Comisión Reguladora de Saneamiento Básico y Agua Potable (CRA). (21 de Abril de 2017). Resolución 788. Por la cual se define el porcentaje de los recursos del recaudo del servicio público de aseo correspondiente a la provisión de inversiones de la actividad de aprovechamiento, en el marco de lo previsto en el artículo 2.3.2.5.3.5 del Decreto 1077 de 2015 modificado y adicionado por el Decreto 596 de 2016. Bogotá, Colombia.

Comisión Reguladora de Saneamiento Básico y Agua Potable (CRA). (09 de julio de 2015). Resolución 720. Por la cual se establece el régimen de regulación tarifaria al que deben someterse las personas prestadoras del servicio público de aseo que atiendan en municipios de más de 5.000 suscriptores en áreas urbanas, la metodología que deben utilizar para el cálculo de las tarifas del servicio público de aseo y se dictan otras disposiciones. Bogotá, Colombia.

Consejo Nacional de Política Económica y Social -CONPES 3874-. (21 de noviembre de 2016). Política Nacional para la Gestión Integral de Residuos Sólidos. Bogotá, Colombia: Departamento Nacional de Planeación.

Elizande, A. (2009). ¿Qué desarrollo puede llamarse sostenible en el siglo XXI? La cuestión de los límites y las necesidades humanas. (U. B. Chile, Ed.) Revista de Educación (Número extraordinario), 53-75.

Fidelis, R., Ferreira, M. A., \& Colmenero, J. C. (2015). Selecting a location to install a plastic processing center: Network of recycling cooperatives. Resources, Conservation and Recycling, 103, 1-8. doi: 10.1016/j.resconrec.2015.07.002

Forrester, J., \& Senge, P. (1980). Tests for building confidence in system dynamics models. Studies in the Management Science (14), 209-228.

Franchetti, M., \& Spivak, A. (2011a). Optimizing the stream. MSW Management, 21(2), 44-51.

Franchetti, M., \& Spivak, A. (2011b). Single stream recycling - A strategy and optimization model for converting from multiple streams to a single stream in Ohio, USA. Journal of Solid Waste Technology and Management, 37(3), 197-209.

doi: 10.5276/JSWTM.2011.197

Guo, H., Hobbs, B., Lasater, M., Parker, C., \& Winch, P. (2016). System dynamics-based evaluation of interventions to promote appropriate waste disposal behaviors in low-income urban areas: A Baltimore case study. Waste Management, 56, 547-560. doi: https://doi.org/10.1016/j.wasman.2016.05.019

Ibarra, D., Redondo, J., \& Peña, C. (2010). Modelo de regionalización para el manejo sostenible de los residuos sólidos municipales. $8^{\circ}$ Congreso Latinoamericano y $8^{\circ}$ Encuentro colombiano de Dinámica de Sistemas. La Dinámica de Sistemas para la efectiva toma de decisiones y análisis estratégico de problemas (pages 31-37). Medellín: Universidad Pontificia Bolivariana.

Kollikkathara, N., Feng, H., \& Yu, D. (2010). A system dynamic modeling approach for evaluating municipal solid waste generation, landfill capacity and related cost management issues. Waste Management, 30, 2194-2203.

doi: https://doi.org/10.1016/j.wasman.2010.05.012

Meira de Sousa Dutra, R., Harue Yamane, L., \& Ribeiro Siman, R. (2018). Influence of the expansion of the selective collection in the sorting infrastructure of waste pickers' organizations: A case study of 16 Brazilian cities. Waste Management, 77, 5058. doi: 10.1016/j.wasman.2018.05.009.

Ministerio de Vivienda, Ciudad y Territorio, 29 de abril 2016. Resolución 276. Por la cual se reglamentan los lineamientos del esquema operativo de la actividad de aprovechamiento del servicio público de aseo. Bogotá, Colombia. 


\section{Sustainability of the usable solid waste market in Bogota (Colombia)}

Naime, R., \& dos Santos, K. L. (2011). Diagnosis of solid waste management in the town of Dois Irmãos - Rio Grande do Sul, Brazil. Revista Brasileira de Gestao e Desenvolvimento Regional, 7(2), 301-314.

Organization of American States (2016). Producción en ciclo cerrado. Facilitando la transición hacia una economía circular en las Américas. recuperado en 15-april-2018

http://www.oas.org/es/sedi/dsd/energia/ciclocerrado/panama/evento_pan/sobre_el_programa_final_pan_091514.pdf

Peña, A., \& Rojas, F. (2013). Modelo sistémico en la gestión de residuos sólidos domiciliarios en la zona metropolitana de Huancayo - Perú. Congreso de Dinámica de Sistemas. Lima: Perú.

Redondo, J. M. (2011). Diagramas causales y arquetipos sistémicos. Bogotá: Departamento de Ciencias Básicas.

Redondo, J., Ibarra-Vega, D., Monroy, L. \& Bermúdez, J., Junio de (2018a). Evaluación de estrategias para la gestión integral de residuos de aparatos eléctricos y electrónicos. DYNA 85 (205), 319-327.

doi: https://doi.org/10.15446/dyna.v85n205.62564

Redondo, J., Olivar, G., Ibarra, D., \& Dyner, I., (April de 2018b). Modeling for the regional integration of electricity market. Energy for sustainable development (43), 100-113. doi: https://doi.org/10.1016/j.esd.2017.12.003

Secretary of Habitat, Special Administrative Unit of Public Services (2016). Plan de Gestión Integral de Residuos Sólidos PGIRS-. Bogotá: Alcaldía Mayor de Bogotá.

Semana Sostenible (01 de marzo de 2020). El 78\% de los hogares colombianos no recicla. Obtenido de https://sostenibilidad.semana.com/medio-ambiente/articulo/el-78-de-los-hogares-colombianos-no-recicla/44231.

Sterman, J. (2000). Business Dynamics: Systems thinking and modeling for a complex world. New York: McGraw-Hill.

Sudhir, V., Srinivasan, G., \& Muraleedharan, V. (1997). Planning for sustainable solid waste management in urban India. System Dynamics Review, 13(3), 223-246. doi: https://doi.org/10.1002/(SICI)1099-1727(199723)13:3<223::AIDSDR127>3.0.CO;2-Q

Sufian, M., \& Bala, B. (2007). Modeling of urban solid waste management system: the case of Dhaka city. Waste Management 27, 858- 868. doi:https://doi.org/10.1016/j.wasman.2006.04.011

Vásquez, Ó. (2005). Modelo de simulación de gestión de residuos sólidos domiciliarios en la Región Metropolitana de Chile. Revista de Dinámica de Sistemas, 1(1), 27-52.

Editor: Rodrigo Firmino

Received: 24 set. 2020

Approved: 18 fev. 2021 